\title{
COGNITIVE ASPECT \\ OF ENGLISH-RUSSIAN METAPHOR TRANSLATION IN JULIAN BARNES'S TALKING IT OVER
}

\author{
Larisa N. Lunkova, Maria S. Pavlova \\ State University of Humanities and Social Studies - GSGU University \\ Russia, Kolomna, Zelyonaya str., 30, 140410
}

\begin{abstract}
The article focuses on the aspects of interpretation of fiction within the framework of cognitive metaphor analysis in Julian Barnes's novel Talking it Over. The article begins with the overview of the major issues and the standard strategies of metaphor translation. Within the present paper translation is viewed as a process with relies on the translator's competence to 'dive into' the source language continuum, i.e. a different social and cultural dimension and disclose the interaction of the mind-scope of the author of the source text and the translator via the dialogue of cultures. There are two reasons due to which metaphor analysis can be conducted. Firstly, metaphors are typical in any natural language, so that's why they can be translated. Secondly, the fact is that translation is always viewed as a phenomenon of cross-cultural communication, whereas metaphor is part and parcel of culture. Metaphor creates a significant challenge for the translator. There are some difficulties in the translation of metaphor. Culturally-bound metaphors are often misunderstood when they are translated from the source language into the target one. Optimizing cross-cultural communication can be done within the "author-text-reader" interpretation triangle when the translation should be accompanied by a cognitive interpretation and lingvocultural commentaries.
\end{abstract}

Key words: translation, translation unit, metaphorical unit, equivalent, image, interpretation, cognitive aspect, dialogue of cultures

\section{INTRODUCTION}

Current theories of translation have developed a range of ambiguous definitions of translation unit. Reflecting on the minimal translation unit, Leonid Barkhudarov suggested that "such unit can have an equivalent in the target text, but its constituent parts, when taken isolated, do not have such equivalents in the target text". Thus, Barkhudarov suggests that a fragment of the source text with an equivalent in the target text may be called a translation unit. In the present study we are treating a metaphorical unit as a translation unit. Metaphor analysis from a translation aspect can be deemed possible due to the following reasons:

1. Metaphors can be translated as metaphor is typical of any natural language.

2. Translation is always viewed as a phenomenon of cross-cultural communication which takes place within the framework of the dialog of cultures, whereas metaphor is part and parcel of culture, unit of the same prominence as concepts, which often breed metaphors.

Being a unit universally used in any language, metaphor, paradoxically, creates a significant challenge for the translator. There are obvious difficulties, pertaining to the translation of metaphor. Difficulties in understanding the translated text by the target language audience are often rooted in the misunderstanding of the culturally-bound 
metaphor. The phenomena which are either absent in the target text culture or visibly differ in source and target text cultures, often hinder efficient cross-cultural interaction of the author and the reader. In order to optimize cross-cultural communication within the 'author-text-reader' interpretation triangle, the mere translation of the metaphor shall not suffice, if not accompanied by a cognitive interpretation and a linguocultural commentary.

Many metaphors, particularly cognitive, are culturally bound, which in turn results in the source text being misread by the recipient. Such metaphorical units can only be understood if the source and target texts are juxtaposed and the target ext in this juxtaposition shall be viewed as a result of cross-cultural communication and a representation of a foreign-language culture in the mind of the recipient.

\section{ANALYZING THE PROBLEM OF METAPHOR TRANSLATION}

The problem of metaphor translation is often viewed in conjunction with the essential property and prerequisite of the sheer existence of a translated text, i.e. equivalence. In this respect special attention should be paid to the works of Eugene Nida, who fairly put it that translation is the closest and the most natural equivalent of the source language text in the target language. Thus, the aim of our study is to extract cognitive information which is stored not only the 'linguistic dimension', but also ensures both cross-cultural and interlingual equivalence during the comparison of source and target text. The first step in retrieving and understanding cognitive information contained in this novel consists in 'chunking' the source text into thematic situations, i.e. Splitting the global macrostrategy which is connected with the theme of the text into microstrategies.

So, in Julian Barnes's novel Talking it Over the main thematic situation is the love triangle between the main characters Oliver, Stuart and Gillian. Their relations become the foundation of such microstrategies as Oliver - Stuart, Oliver - Gillian, Stuart - Gillian. We believe these links are the main in the text.

In order to decode the Oliver - Gillian link, we have to look at the text itself. Cognitive strategies of quality textual changes facilitate the extraction of information concerning the appearance of the protagonists, their emotional state and interpersonal relations. The quality property of such constructs is inherent in the formal structure with not only nominal, but also attributive limited metaphorical content with the meaning of property, size, colour, form and shape of the item (e.g., tranquil eyes, out of my skull with happiness; But what I needed them for was to deliver the heart, rubescent and entire, he really did blush at that. Completely scarlet. Even his ears went bright red.) The information retrieval paradigm of quality of metaphorical units of the source text is based on the repeated use of metaphorical models which create a close interrelation between the external image and the inner world of the protagonist - Oliver. Let us look at the situation in more detail in order to retrieve the cognitive information about Oliver - Stuart microstrategy:

So I strolled amid the base huts sheltering those far-flung operatives of commerce, waiting for the heat of the day to draw the moisture from my 60/40 silk/viscose trouser mix. That's what I feel like myself, and rather too often, if you must know: 60 per cent silk and 40 per cent viscose. Sleek but inclined to rumple. Whereas Stuart is 100 per cent man-made fibre: hard to crush, easy to wash, simple to drip-dry, stains merely lift out (J. Barnes. Talking it over). 
Looking the present description at the lexical level, we see that the author uses genuine metaphors to juxtapose the protagonists. This assumption is confirmed by the following metaphorical situation We are cut from a different cloth, Stu and I. While translating this metaphor into Russian, the translator tried to retain the same metaphorical image, while making it more familiar for the target language audience:

Mbl со Стю выстроены из разных материй (My so Styu vystroeny iz raznych materij - Stu and I are built from the matter of different sorts).

Thus the confrontation between Oliver and Stuart becomes apparent. The author very skillfully uses juxtaposition as a special means of creating the concept, which in turn contributes to the aesthetics of the novel. Nearly all interpersonal relations are given by the author based on the juxtaposition of the characters of the protagonists. Oliver compares the composition of his trousers with his own character and the character of Stuart:

That's what I feel like myself, and rather too often, if you must know: 60 per cent silk and 40 per cent viscose. Sleek but inclined to rumple. Whereas Stuart is 100 per cent man-made fibre: hard to crush, easy to wash, simple to drip-dry, stains merely lift out.

In this instance the author himself provides the explanation, so that the ground of the metaphor was more evident and thus understandable for both the reader and the translator.

В то время как Стюарт - стопрочентный хэ-бэ, тканный вручную, - несминаемый, легко стирается, сохнет без выжимания, пятна не остаются (V to vremya kak Styuart - stoprotsentnyy khe-be. tkannyy vruchnuyu. - nesminayemyy. legko stirayetsya. sokhnet bez vyzhimaniya. pyatna ne ostayutsya. - Whereas Stuart is one hundred percent hand-woven cotton wool, uncreasable, easily washed, dries without squeezing, spots do not remain).

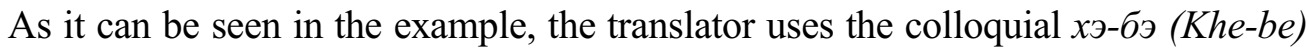
for fibre, thus retaining the metaphorical image, which remains natural for the Russian reader. Thus, from the perspective of cognitive metaphor translation theory the cultural component which is the ground of the conceptual metaphor allows to trace certain similarities in how human experience is structured in different cultures. In this example we can see that the projection from one sphere to the other in metaphors is similar in both source and target languages, which is a manifestation of a conceptual shift between two languages. Having analyzed the translation of the metaphor within the framework of the suggested scenario, we can see that these metaphors are similar in both source and target languages and cannot be viewed as an example of the 'cultural distance' issue.

\section{CORRECT CONCEPTUALIZATION OF THE METAPHORICAL IMAGE}

Naturally, the extraction of cognitive information from metaphors requires not only sheer knowledge, but also opinions, values and emotions required for the correct conceptualization of the metaphorical image. According to P. Newmark, metaphor translation fully depends on the type of the text in which it is employed. Newmark singles out two types of texts:

1) informative, in which lexicalized metaphors are not functionally loaded and thus have higher translatability and 
2) expressive, in which metaphors convey a lot of information and have low translatability as they contain contextual, semantic and pragmatic information.

Here is an example of an informative metaphorical context:

I have this game with myself, me and Linzi both play it, you decide how fanciable someone is. If they're not very fanciable, you say, 'He's only a Tuesday,' meaning if he asked you out you'd only keep one night of the week free for him. The best is to call someone 'Seven Days of the Week', which means you'd keep every day free if he asked. So this boy is looking at the irises and I'm doing the VAT on a multiple despatch but I'm also looking out of the corner of my eye and thinking, 'You're a Monday to Friday'.

Let us look at the target language version and asses the level of translatability of the italicized metaphors:

А у нас с Линзи такая игра: мы ставим им отметки в днях недели. Если не очень нравится, мы говорим: «Этот - на вторник». В смысле, если пригласит, можно уделить ему из всей недели один вечер. А высший бал — «Семь дней в неделю». То есть для него, если позовет, - хоть каждый вечер. Ну, так вот, этот парень рассматривает ирисы, я заполняю ведомость по налогу на добавленную стоимость, а сама поглядываю на него краем глаза и думаю: «Tbl-c понедельника по пятницу».

(A u nas s Linzi takaya igra: my stavim im otmetki v dnyakh nedeli. Esli ne ochen nravitsya. my govorim: 'Etot - na vtornik'. V smysle. esli priglasit. mozhno udelit emu iz vsey nedeli odin vecher. A vysshiy bal - 'Sem dney v nedelyu'. To est dlya nego. esli pozovet. - khot kazhdyy vecher. Nu. tak vot. etot paren rassmatrivayet irisy. ya zapolnyayu vedomost po nalogu na dobavlennuyu stoimost. a sama poglyadyvayu na nego krayem glaza i dumayu: 'Ty — s ponedelnika po pyatnitsu' — Linzy and I, we have a kind of game: we put marks on weekdays. If we do not particularly like it we say: This one for Tuesday. In the sense, if he invites we can give him only one evening of the whole week. So this guy observes the irises, I fill in the VAT form, while watching him with a corner of my eye and think: You are from Monday to Friday.)

The context below shows that the italicized metaphors were retained in the target language, they are not functionally loaded, thus, they are highly translatable.

Expressive metaphorical context poses a certain difficulty for the translator. In this case translation should be viewed as a process with relies on the translator's competence to 'dive into' the source language continuum, i.e. a different social and cultural dimension and disclose the interaction of the mind-scope of the author of the source text and the translator via the dialogue of cultures.

OK, OK, I feel a bit bad, but what would you have done? I know, you wouldn't have been there in the first place. But I was, and that's always going to be the brute difference between us, isn't it? Still, did you cop the panache? I have to hand it to myself, I really do. And what about the Ancient Mariner sleeve-tugging aspect? That worked out really well, didn't it? I've always said, if you want to outwit an Englishman, touch him when he doesn't want to be touched. Hand on the arm plus emotional confession. They can't bear that, the Anglos, they'll cringe and shiver and swallow whatever you tell them. 'Like trying to ease an oyster into a parking meter.' Did you see Stuart's face when I left him? What a cameo of tender concern. 
The main prerequisite for adequate translation of such metaphorical units and consequent communication is the achieving of the so-called 'sense contact' which is based on the alignment of the 'sense focuses' of the generated text and the text under interpretation. Such 'focuses of meaning' function as a platform for efficient interaction between the author and the translator in the situation of cross-cultural communication. For example, the first metaphor feel a bit bad was translated into Russian as ucnblmblвать некоторые угрызения совести (ispytyvat' nekotorye ugryzeniya sovesti-feel some twinges of conscience). The sense focuses of the metaphor in the source and target texts do not coincide, which in turn means that the metaphor in the target text contains new associations. The phrase feel bad means to feel bad physically, whereas its Russian translation испытывать некоторые угрызения совести (ispytyvat' nekotorye ugryzeniya sovesti - feel some twinges of conscience) are more likely to be associated with the morality of the character. The metaphor did you cop the panache acquired in the Russian translation certain features an idiom and in this particular instance we can only speak of apparent equivalence of the translation of the metaphor разве я не заслужил перо в шляпу? (razve ya ne zasluzhil pero $v$ shlyapu? - did I not deserve a feather in my hat?) as related to that in the source text. While modeling the contextual equivalent for the target text in Russian, the translator acts an interpreter of conceptual information on which the metaphor is based. Feathers in headwear symbolize power and triumph. This symbol in particular help to interpret the metaphorical situation correctly and understand the joy of the protagonist. And what about the Ancient Mariner sleeve-tugging aspect? That worked out really well, didn't it?

\section{CONCLUSION}

The cognitive aspect of metaphor translations allows to study the deeper meaning of the particular metaphorical unit in the target language and understand the concept of the whole work of fiction. The intellectual and emotional perception of the text, understanding of its meaning happens on this stage. Despite this, the following strategies for metaphor translation were implemented here:

1) retaining the same metaphorical image, but making it more natural for the speakers of the target language;

2) replacement of a metaphor with other equivalent metaphor;

3) retaining the metaphorical image with additions of explanations which make the ground of the metaphor more understandable.

At the same time it should be noted that the degree of translatability of any metaphor from any source language depends of the specific knowledge of the souse language culture and the semantic associations which were added to the metaphor, as well as the translation potential of the metaphor, i.e. the chance of failure to translate the metaphor which depends on the particular situation.

(C) Larisa N. Lunkova, Maria S. Pavlova Article history:

Received: 15.09.2018

Accepted: 12.10.2018 


\title{
REFERENCES
}

1. Barnes, J. (2004). Talking it Over. Love, etc. Metroland Novels. Moscow: AST Publishing House, LLC: OJSC 'LUKS'.

2. Barkhudarov, L.S. (1975). Language and Translation. Aspects of General and Special Translation Theory. Moscow: Mezhdunarodnie Otnosheniya.

3. Dridze, T.M. (1996). Socail Communication As Textual Activity In Semiosociopsycology. Obshchestvennyye nauki i sovremennost, 3, 145-152.

4. Kuznetsov, V.G. (2011). Cognitive Aspect of Implicit Motivation of the Language Sign. Voprosy kognitivnoy lingvistiki, 1, 15-22.

5. Markovina, I.Yu. \& Sorokin, Yu.A. (2008). Culture and text. Introduction to Lacunology: A Textbook. Moscow: GEOTAR-Media.

6. Fosenko, T.A. (2002). Translation Process Modeling Within The Context Of Matter of Consciousness. In Mezhkulturnaya kommunikatsiya i problemy natsionalnoy identichnosti: Sb. nauch. tr. Voronezh: Voronezh. Gos. un-t. pp. 125-134.

7. Barnes, J. (1991). Talking it over. Vintage Books: Random House, Inc., New York.

8. Newmark, P. (1998). The Translation of Metaphor. Approaches to Translation. New York.

УДК: 81'255.2:821.111-31

DOI: $10.22363 / 2313-2299-2018-9-4-904-910$

\section{КОГНИТИВНЫЙ АСПЕКТ ПЕРЕВОДА МЕТАФОРЫ НА МАТЕРИАЛЕ РОМАНА ДЖ. БАРНСА «КАК ВСЕ БЫЛО»}

\author{
Л.Н. Лунькова, М.С. Павлова \\ Государственный социально-гуманитарный университет \\ Россия, Коломна, ул. Зеленая, 30, 140410
}

\begin{abstract}
Статья рассматривает вопросы интерпретации художественного текста через когнитивный анализ метафор на примере романа Дж. Барнса «Как все было». Анализируются основные проблемы перевода метафор, а также принимаются во внимание традиционные правила перевода метафоры. В контексте данной работы перевод рассматривается как процесс, основанный на способности переводчика погрузиться в континуум другого языка, в иное социокультурное измерение и продемонстрировать взаимодействие сознаний автора и переводчика через диалог культур. В статье предлагаются две причины анализа метафоры. Первая причина состоит в том, что перевод метафорических единиц возможен, так как метафора является принадлежностью любого языка. Вторая причина заключается в том, что перевод всегда рассматривается как феномен межкультурной коммуникации, осуществляемой в рамках диалога культур. Перевод метафоры представляет определенную сложность для переводчика. Например, трудности восприятия реципиентом иноязычного текста обычно обусловлены неадекватным пониманием значения метафор с культурной составляющей. Для оптимизации межкультурного общения в рамках герменевтического треугольника автор-текст-читатель необходим не только перевод метафорических единиц с языка оригинала на родной язык, но и когнитивная интерпретация метафор и лингвокультурный комментарий.
\end{abstract}

Ключевые слова: перевод, единица перевода, метафорическая единица, эквивалент, образ, интерпретация, когнитивный аспект, диалог культур

\section{БИБЛИОГРАФИЧЕСКИЙ СПИСОК}

1. Барнс Д. Как все было. Любовь и так далее. Метроленд. М.: АСТ, Люкс, 2004.

2. Бархударов Л.С. Язык и перевод (Вопросы общей и частной теории перевода). М.: Междунар. отношения, 1975. 
3. Дридзе T.M. Социальная коммуникация как текстовая деятельность в семиосоциопсихологии статья // Общественные науки и современность. 1996. № 3. С. 145-152.

4. Кузнецов В.Г. Когнитивный аспект имплицитной мотивированности языкового знака // Вопросы когнитивной лингвистики. 2011. № 1. С. 15-22.

5. Марковина И.Ю., Сорокин Ю.А. Культура и текст. Введение в лакунологию: учебник. M.: GEOTAR-Media, 2008. C. 32.

6. Фосенко T.A. Моделирование процесса перевода в контексте метатеории сознания. Межкультурная коммуникация и проблемы национальной идентичности: Сб. науч. тр. Воронеж: Воронеж. гос. ун-т, 2002. C. 125-134.

7. Barnes J. Talking it over. Vintage Books: Random House, Inc., N-Y, 1991.

8. Newmark P. The Translation of Metaphor. Approaches to Translation. N-Y, 1998.

\section{Для цитирования:}

Лунькова Л.Н., Павлова М.С. Когнитивный аспект перевода метафоры на материале романа Дж. Барнса «Как все было» // Вестник Российского университета дружбы народов. Серия: Теория языка. Семиотика. Семантика. 2018. Т. 9. № 4. С. 904-910. doi: 10.22363/2313-22992018-9-4-904-910.

\section{For citation:}

Lunkova, L.N. \& Pavlova, M.S. (2018). Cognitive Aspect of English-Russian Metaphor Translation in Julian Barnes's Talking it Over. RUDN Journal of Language Studies, Semiotics and Semantics, 9(4), 904-910. doi: 10.22363/2313-2299-2018-9-4-904-910.

\section{Сведения об авторах:}

Лунькова Лариса Николаевна, доктор филологических наук, профессор кафедры английского языка факультета иностранных языков Государственного социально-гуманитарного университета. Сфера научных интересов: теоретическое и прикладное языкознание, анализ текста и дискурса; e-mail: lora@list.ru

Павлова Мария Сергеевна, аспирант четвертого года обучения на кафедре лингвистики и межкультурной коммуникации факультета иностранных языков Государственного социальногуманитарного университета. Сфера научных интересов: анализ текста и дискурса, интерпретация текста; e-mail: marija-pavlova1993@yandex.ru

\section{Information about the authors:}

Lunkova Larisa Nikolaevna, Dr. habilis, Professor of the English Language Department, Faculty of Foreign Languages. Sphere of scientific research: theoretical and applied linguistics, text and discourse analysis; e-mail: lora@list.ru

Pavlova Maria Sergeevna, a fourth year PhD student of the Linguistics and Cross-Cultural Communication Department, Faculty of Foreign Languages. Sphere of scientific research: text and discourse studies, text analysis; e-mail: marija-pavlova1993@yandex.ru 